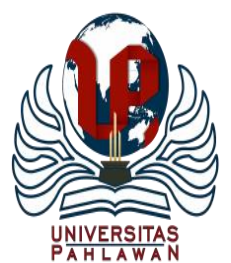

Edukatif : Jurnal Ilmu Pendidikan Volume 3 Nomor 5 Tahun 2021 Halm 2944 - 2951 EDUKATIF: JURNAL ILMU PENDIDIKAN

Research \& Learning in Education

https://edukatif.org/index.php/edukatif/index

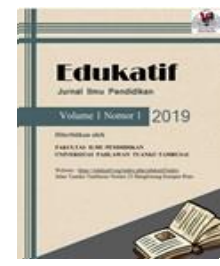

\title{
Kepemimpinan Kepala Sekolah dalam Pengambilan Keputusan di Sekolah Dasar
}

\author{
Dilla Yuliatika $^{1 凶}$, Rusdinal $^{2}$, Nurhizrah Gistituati ${ }^{3}$ \\ Universitas Negeri Padang, Indonesia ${ }^{1,2,3}$ \\ E-mail : $\underline{\text { dillayuliatika1@ gmail.com }}{ }^{1}, \underline{\text { rusdinal@ @ip.unp.ac.id }}^{2}, \underline{\text { icha up @ yahoo.com }}^{3}$
}

\begin{abstract}
Abstrak
Penelitian ini bertujuan untuk mengkaji kepemimpinan kepala sekolah dalam mengambil keputusan tentang pelanggaran disiplin di SDN 01 Gurun. Penelitian ini tergolong penelitian kualitatif dengan desain studi kasus. Narasumber penelitian ini adalah guru, kepala sekolah, dan siswa. Teknik pengumpulan data melalui wawancara, observasi dan dokumentasi. Triangulasi metode yang digunakan dalam penelitian ini adalah triangulasi sumber. Hasil dari penelitian ini menunjukkan: 1) proses pengambilan keputusan dilihat dari bagian mengidentifikasi masalah, yaitu dengan mengetahui jenis pelanggaran disiplin, mengelompokkan jenis-jenis pelanggaran tata tertib yang dilakukan baik oleh peserta didik ataupun guru, kemudian menemukan dan memutuskan jenis sanksi dan solusi untuk jenis pelanggaran disiplin, lalu memberikan sanksi yang sesuai dengan bentuk kesalahan yang telah diperbuat, 2) proses pengambilan keputusan dilihat dari sudut pandang penyebab terjadinya, kepala sekolah dituntut untuk dapat memahami pendidik dan siswa lebih dalam; memperhatikan pelanggaran yang dilakukan oleh siswa dan pendidik dan mencari alasan pelanggaran; mencari dan menemukan unsur-unsur yang menyebabkan siswa dan pendidik mengabaikan disiplin; menjelaskan alasan pelanggaran yang dilakukan dan mencari penyebabnya, 3) proses pengambilan keputusan dilihat dari dampaknya bagi guru dan siswa yaitu kepala sekolah harus mengetahui jenis pelanggaran dan akibatnya, mengawasi guru dan siswa, menjalin komunikasi dan sosialisasi kepada siswa untuk menjaga kebersihan; mendorong partisipasi aktif guru untuk membangun karakter dan perilaku siswa, dan memberitahu guru untuk tidak menunjukkan perilaku yang tidak baik di depan siswa.

Kata kunci: pengambilan keputusan, kepemimpinan.
\end{abstract}

\begin{abstract}
This study aims to examine the principal's leadership in making decisions about disciplinary violations at SDN 01 Gurun. This research is classified as a qualitative research with a case study design. The sources of this research are teachers, principals, and students. Data collection techniques through interviews, observation and documentation. The triangulation method used in this research is source triangulation. The results of this study indicate: 1) the decisionmaking process is seen from the identifying problem section, namely by knowing the types of disciplinary violations, classifying the types of disciplinary violations committed by both students and teachers, then finding and deciding the types of sanctions and solutions for these types of violations. violation of discipline, then impose sanctions in accordance with the form of the error that has been made, 2) the decision-making process is seen from the point of view of the cause of the occurrence, the principal is required to be able to understand educators and students more deeply; pay attention to violations committed by students and educators and look for reasons for violations; seek and find the elements that cause students and teachers to ignore discipline; explain the reasons for the violations committed and look for the causes, 3) the decision-making process seen from the impact on teachers and students, namely the principal must know the types of violations and their consequences, supervise teachers and students, establish communication and socialization to students to maintain cleanliness; encourage active participation of teachers to build students' character and behavior, and tell teachers not to show bad behavior in front of students.
\end{abstract}

Keywords: decision making, leader.

Copyright (c) 2021 Dilla Yuliatika, Rusdinal, Nurhizrah Gistituati

$\triangle$ Corresponding author

Email : dillayuliatika1@gmail.com

DOI $\quad$ : https://doi.org/10.31004/edukatif.v3i5.972 
2945 Kepemimpinan Kepala Sekolah dalam Pengambilan Keputusan di Sekolah Dasar - Dilla Yuliatika, Rusdinal, Nurhizrah Gistituati

DOI: https://doi.org/10.31004/edukatif.v3i5.972

\section{PENDAHULUAN}

Kepemimpinan merupakan bagian dasar dari kehidupan manusia. Kepemimpinan itu kokoh sampaisampai mempengaruhi pelaksanaan kinerja organisasi sehingga dapat dikatakan bahwa keterpurukan pendidikan disebabkan karena kepemimpinan yang tidak dapat menyesuaikan diri dengan perubahan. Selain itu, Thoha juga mengatakan bahwa sebuah organsasi akan berhasil ataupun mengalami keterpurukan ditentukan oleh kepemimpinan (Miftah, 2012). Untuk situasi ini, jelas, kepemimpinan seperti apa yang dilakukan oleh kepala sekolah sebagai seorang pemimpin.

Lembaga-lembaga pendidikan terus-menerus menghasilkan pionir yang dapat menggerakkan dan mempengaruhi masyarakat. Seperti halnya lembaga pada umumnya, sekolah membagi kegiatan ini menjadi bagian-bagian tertentu, di mana pejabat publik sekolah dilibatkan sebagai pihak untuk melaksanakan kegiatan tersebut sesuai dengan jabatannya masing-masing. Mulai dari guru atau pendidik, pengelola TU, kepala sekolah dan seluruh tim yang ada terkait erat dengan setiap tindakan sekolah. Kegiatan ini terus membangun sekolah menjadi organisasi yang dapat mewujudkan visi dan misinya dengan baik.

Sekolah merupakan lembaga pendidikan yang dipimpin langsung oleh seorang kepala sekolah. Kepala sekolah memilki kewajiban untuk memegang fungsi sebagai administrator. Sebagai seorang administrator kepala sekolah bertanggung jawab untuk mengelola dan mengatur bawahannya, dalam hal ini yaitu guru dan staf di sekolah. Tugas dan tanggung jawab yang harus dimiliki seorang kepala sekolah yaitu sebagai supervisor, dimana supervisor ini bertanggung jawab untuk membina bawahannya di sekolah.

Dari berbagai kegiatan di sekolah, ada kegiatan yang merupakan kunci utama dari pencapaian keberhasilan sekolah. Kegiatan ini adalah pengambilan keputusan yang yang sangat penting karena terdapat peran kepala sekolah sebagai pemimpin di sekolah. Pengambilan keputusan dapat menjadikan sekolah sebagai organisasi pendidikan yang tetap mempertahankan vitalitasnya di tengah hambatan dan ancaman yang dihadirkan oleh internal dan eksternal sekolah.

Kepala SDN 01 Gurun, Kecamatan Sungai Tarab, berulang kali mengalami pergantian. Setiap pemimpin memiliki gaya kepemimpinan yang berbeda. Semua guru dan siswa pasti percaya bahwa kepala sekolah dapat melakukan perubahan ke arah yang lebih unggul. Asumsi dari guru atau siswa lain adalah bahwa setiap prestasi yang dicapai siswa dan guru dapat cukup menonjol untuk diperhatikan, diapresiasi, dan diakui dari pimpinan, sehingga dapat membangun inspirasi siswa dan pengajar untuk berprestasi jauh lebih unggul.

Berdasarkan pengalaman yang dialami oleh para pengajar di SDN 01 Gurun Kecamatan Sungai Tarab, setelah beberapa kali pergantian kepala sekolah, terungkap bahwa masing-masing kepala sekolah mempunyai gaya dan tipe kepemimpinan yang berbeda-beda. Administrator dituntut memiliki kemampuan untuk dapat mengambil keputusan dengan cepat, tepat dan diketahui oleh seluruh kalangan yang terkait dengan sekolah.

Sebagian masalah yang dilihat oleh kepala SDN 01 Gurun, Kecamatan Sungai Tarab, Kabupaten Tanah Datar, adalah masalah yang diidentifikasi oleh siswa dan pengajar. Hal-hal yang terkait dengan pelanggaran tata tertib oleh siswa di sekolah termasuk rendahnya bantuan orang tua untuk anak-anak mereka, masih banyak siswa yang kurang disiplin, misalnya, datang lebih lambat dari yang diharapkan, sering berkelahi di sekolah, tidak berpakaian rapi dan lengkap. Untuk permasalahan pelanggaran tata tertib yang dilakukan oleh tenaga pendidik antara lain masih terdapat guru atau tenaga pendidik yang terlambat datang ke ruang kelas, belum adanya perhatian guru untuk membina keterampilannya, dan belum adanya kerjasama antar pendidik di sekolah. Isu lain yang dilihat oleh kepala sekolah adalah isu yang bersumber dari iklim di sekitar sekolah seperti persaingan antar sekolah dan keterkaitan antara sekolah dengan lingkungan sekitar sekolah. Sebagian dari persoalan yang telah dipaparkan di atas adalah beberapa aspek yang harus di perhatikan dan ditindaklanjuti oleh Kepala SDN 01 Gurun dengan proses pengambilan keputusan yang dapat memperlancar jalannya proses pembelajaran di sekolah. 
2946 Kepemimpinan Kepala Sekolah dalam Pengambilan Keputusan di Sekolah Dasar - Dilla Yuliatika, Rusdinal, Nurhizrah Gistituati

DOI: https://doi.org/10.31004/edukatif.v3i5.972

\section{METODE PENELITIAN}

Penelitian ini di golongkan kepada jenis penelitian kualitatif. Penelitian ini menggunakan rancangan studi kasus, di mana studi kasus adalah penelitian yang menganalisis secara lebih mendalam tentang orang, kelompok, atau organisasi yang diselesaikan dalam waktu tertentu.

Penelitian dilakukan di SDN 01 Gurun Kecamatan Sungai Tarab. Informan dalam penelitian ini yaitu guru, kepala sekolah, dan siswa. Penelitian ini dilakukan selama 2 bulan, yaitu bulan Maret sampai April. Pengumpulan data pada dilakukan melalui teknik wawancara, observasi lapangan dan dokumentasi. Analisis data dilakukan dalam penelitian ini yaitu menggunakan beberapa langkah yaitu pengumpulan data, reduksi data, dan penarikan kesimpulan.

\section{HASIL DAN PEMBAHASAN PENELITIAN}

\section{Konsep Kepemimpinan}

Kepemimpinan dalam bahasa Inggris berarti "leadership", dimana berasal dari kata "leader" yang berarti pemimpin yang memiliki beberapa arti yang saling berkaitan, yaitu: mengambil langkah awal, mengarahkan pikiran-pendapat orang lain, membimbing, menuntun, dan menggerakkan orang lain melalui pengaruhnya (Baharuddin dan Umiarso, 2012).

Menurut Hersey dan Blanchard, dalam (Chaniago Aspizain, 2017),“pemimpin adalah seseorang yang dapat mempengaruhi orang lain atau sekelompok orang agar dapat melakukan aktivitas atau kerja yang telah ditetapkan sesuai dengan tujuan organisasi”. Kepala sekolah sebagai seorang pemimpin adalah orang yang selalu melihat melampaui orang lain yang melihat. Tidak semua pemimpin mampu menciptakan kondisi sekolah yang di harapkan (Pratama et al., 2020). Untuk menciptakan kondisi sekolah yang di harapkan, peranan kepala sekolah dalam mengambil keputusan sangat di butuhkan agar kondisi sekolah menjadi lebih baik. Selain itu untuk meningkatkan mutu pendidikan, sangat diperlukan peranan pemimpin, hal ini disebabkan esensi dari pemimpin yang merupakan usaha untuk mempengaruhi orang lain agar menyumbangkan keahliannya, baik untuk bertindak sesuai kapasitas yang dimiliki maupun untuk tumbuh dan berkembang secara terus menerus (Suyitno, 2021).

\section{Pengambilan Keputusan}

Pengambilan keputusan merupakan suatu proses merumuskan beberapa alternatif tindakan dalam menghadapi berbagai kondisi dan situasi serta menetapkan pilihan yang tepat diantara beberapa alternatif penyelesaian masalah yang ada setelah diadakan evaluasi terhadap efektif atau tidaknya alternatif tersebut untuk mencapai tujuan (Purwanto Indra, 2019).

Pengambilan keputusan adalah sesuatu yang penting bagi seorang pimpinan pendidikan, karena memiliki peran penting dalam memotivasi, kepemimpinan, koordinasi, komunikasi dan terjadinya perubahan dalam suatu organisasi. Tujuan dari pengambilan keputusan yaitu untuk menyelesaikan masalah.

Proses atau langkah-langkah dalam pengambilan keputusan diawali dengan proses identifikasi masalah, mengumpulkan dan menganalisis data, membuat beberapa alternatif-alternatif keputusan/kebijakan, memilih salah satu alternatif yang dirasa paling baik atau terbaik, melaksanakan keputusan, melakukan pemantauan dan mengevaluasi pelaksanaan dari keputusan (Purwanto Indra, 2019).

\section{Kepala Sekolah Sebagai Seorang Pengambil Keputusan di Sekolah}

Proses Pengambilan Keputusan Dilihat Dari Identifikasi Masalah Mengenai Pelanggaran Tata Tertib Yang Dilakukan Oleh Guru Dan Siswa

Hasil penelitian memperlihatkan bahwa proses pengambilan keputusan yang dilakukan oleh kepala sekolah dilihat dari cara mengidentifikasi permasalahan terkait pelanggaran tata tertib yang dilakukan oleh 


\section{Kepemimpinan Kepala Sekolah dalam Pengambilan Keputusan di Sekolah Dasar - Dilla Yuliatika, Rusdinal, Nurhizrah Gistituati}

DOI: https://doi.org/10.31004/edukatif.v3i5.972

guru ataupun siswa, yang pertama adalah dengan mengetahui jenis pelanggaran yang dilakukan oleh peserta didik. Hasil penelitian menunjukkan terdapat beberapa bentuk pelanggaran tata tertib yang dilakukan oleh peserta didik, antara lain: peserta didik yang terlalu sering terlambat datang ke sekolah, tidak mengerjakan tugas dan tugas sekolah, tidak menjaga kebersihan diri dan sekolah, sering berkelahi dengan teman, dan berbagai jenis pelanggaran lainnya. Langkah selanjutnya yang dapat dilaksanakan kepala sekolah yaitu mengelompokkan jenis-jenis pelanggaran tata tertib yang dilakukan peserta didik dengan pengelompokan pelanggaran ringan, sedang dan berat. Sesuai dengan hasil pemeriksaan (Ningsih, 2014) bahwa siswa yang menyalahgunakan peraturan sekolah harus diberikan sanksi sesuai dengan perbuatannya. Sanksi yang diberikan oleh kepala sekolah harus sesuai dengan perbuatan siswa. Dengan demikian, langkah dalam membedakan dan mengelompokkan jenis pelanggaran ini penting untuk seorang administrator sekolah dalam pegambilan keputusan selanjutnya.

Setelah kepala sekolah mengetahui dan mengklarifikasikan jenis-jenis pelanggaran tata tertib yang dilakukan oleh murid, tahap selanjutnya yang harus dilakukan kepala sekolah adalah mencari dan menetapkan bentuk sanksi dan solusi atas jenis-jenis pelanggaran tata tertib yang dilakukan oleh peserta didik.

Tahapan selanjutnya yang kepala sekolah harus laksanakan adalah dengan memberikan sanksi yang sesuai dengan bentuk kesalahan yang telah diperbuat. Kepala Sekolah dapat mengambil keputusan atas jenis pelanggaran ringan yang dilakukan oleh siswa, misalnya dengan memberikan teguran yang tidak menyebabkan siswa tertekan atas pemberitahuan tersebut. Selain itu, untuk jenis pelanggaran sedang, kepala sekolah dapat memberikan teguran, misalnya pemberitahuan kepada siswa yang diikuti dengan himbauan kepada orang tua siswa. Untuk jenis pelanggaran yang tergolong berat, sanksi yang diberikan seperrti pemberitahuan diikuti dengan surat teguran kepada orang tua peserta didik. Menurut (Marliana, Ayu, 2013) bahwa teknik sekolah untuk mengatasi pelanggaran ketertiban pada peserta didik adalah dengan melakukan pembinaan, pemberian sanksi disiplin bagi pelanggar tata tertib, pemberian skor pelanggaran, dan membicarakan masalah ini dengan wali muridnya. Teknik-teknik ini termasuk bagian sentral sebagai pemimpin. Selain itu (Julia, 2013) juga mengemukakan dalam penelitiannya bahwa salah satu langkah dan upaya yang dapat dilakukan oleh seorang guru untuk mengatasi pelanggaran disiplin yang dilakukan oleh peserta didik yaitu dengan mengevaluasi pelanggaran terserbut, memberikan sanksi yang jelas dan mendidik.

Pelanggaran terhadap tata tertib terkadang juga sering dilakukan oleh para pendidik di sekolah. Mengenai masalah ini, kepala sekolah dapat melakukan langkah awal, misalnya kepala sekolah melihat dan mengklasifikasikan jenis pelanggaran tata tertib yang dilakukan oleh guru. Selanjutnya adalah dengan mencari dan menetapkan bentuk sanksi dan solusi atas pelanggaran tata tertib tersebut. Hal ini senada dengan penelitian (Fitriwati, C., Sulistyarini, 2015) yang menjelaskan bahwa ada beberapa langkah dalam pengambilan keputusan, yaitu dimulai dari pemberian hukuman terhadap pelanggaran yang dilakukan, hal ini dilakukan melalui empat tahapan, yaitu tahap pemberitahuan, pemberian teguran atau peringatan, dan pemberian hukuman.

Selanjutnya kepala sekolah memutuskan sanksi bagi guru yang melakukan pelanggaran, kepala sekolah dapat memberikan sanksi sesuai keputusan yang sudah diambil sebelumnya selaras dengan jenis pelanggaran yang telah diperbuat. Kepala sekolah. dapat memberi sanksi untuk jenis pelanggaran ringan yang dilakukan oleh guru, seperti memanggil guru, untuk jenis pelanggaran sedang, misalnya, melakukan diskusi internal dengan guru yang bersangkutan, dan sanksi yang didapat akibat melakukan pelanggaran berat yaitu berupa supervisi atau pembinaan yang diberikan oleh pengawas.

\section{Proses Pengambilan Keputusan Dilihat Dari Penyebab Terjadinya Pelanggaran Tata Tertib Yang Dilakukan Oleh Guru dan Siswa}

Hasil penelitian menunjukkan bahwa proses pengambilan keputusan dilihat dari alasan guru dan siswa melanggar aturan, dan langkah yang dapat dilakukan kepala sekolah adalah memahami pendidik dan siswa 


\section{Kepemimpinan Kepala Sekolah dalam Pengambilan Keputusan di Sekolah Dasar - Dilla Yuliatika,}

Rusdinal, Nurhizrah Gistituati

DOI: https://doi.org/10.31004/edukatif.v3i5.972

lebih dalam. Kepala sekolah dapat menangani guru dan siswa yang melanggar aturan dengan mengkomunikasikan permasalahan yang dihadapi pendidik dan peserta didik tersebut. Hal ini diperkuat dengan hasil penelitian (Lee, Cheah; Abdullah, Abdul Gani Kanesan; Ismail, Aziah; Alizydeen, 2011) yang menjelaskan bahwa kepala sekolah selalu mendengarkan guru dan siswanya terkait permasalahan yang sedang dialami.

Tahap selanjutnya yang dilakukan oleh kepala sekolah yaitu dengan memperhatikan jenis pelanggaran yang diperbuat oleh para pendidik dan peserta didik, kemudian mencari penyebab terjadinya pelanggaran tersebut. Kepala sekolah mencoba untuk menemukan variabel yang menyebabkan siswa dan guru melakukan pelanggaran ini. Penemuan-penemuan di lapangan, salah satu penyebab pelanggaran yang dilakukan oleh siswa diidentikkan dengan masalah keuangan, tidak adanya orang tua yang perhatian terhadap anaknya, orang tua bersikap otoriter, sehingga masih banyak siswa yang tidak belajar dan mengerjakan tugas yang diberikan guru di rumah. (Simuforosa, M. dan Rosemary, 2014) dalam penelitiannya menjelaskan bahwa yang menyebabkan ketidaksiplinan siswa yaitu masalah yang berasal dari lingkungan keluarga siswa itu sendiri, sehingga hal tersebut mempengaruhi perilaku siswa di sekolah. Pernyataan ini juga diperkuat dengan hasil penelitian (Gutuza, Regis F. dan Mapolisa, 2015) yang mengemukakan bahwa penyebab dari ketidaksiplinan siswa di sekolah yaitu berasal dari tekanan teman sebaya, perilaku dari gurunya, peniadaan hukuman fisik, penyalahgunaan obat-obatan, faktor latar belakang keluarga, dan sebagainya. Selain itu, penyebab pelanggaran menurut penelitian (Freire, Isabel dan Amado, 2009) juga terjadi karena adanya kemungkinan ada hubungan antara tindakan disiplin yang tidak konsisten dan/atau tindakan disipliner berdasarkan hukuman dan kontrol dan lebih sering terjadinya perilaku tidak disiplin di murid.

Jenis pelanggaran yang dilakukan oleh tenaga pendidik juga harus diperhatikan oleh kepala sekolah dan mencari penyebab dari pelanggaran tersebut terjadi. (Ngwokabuenui, 2015) menjelaskan dalam penelitiannya bahwa ketidakdisiplinan merupakan suatu tindakan ketidaktaatan guru yang tidak dapat untuk diterima. Seorang administrator perlu mendengarkan dan berdiskusi dengan guru terkait mengenai faktor-faktor yang menyebabkannya melakukan pelanggaran. Pelaksanaan diskusi ini akan berdampak pada guru yang akan merasa dihargai dan mendapat pengakuan dari kepala sekolah, dan ini akan memancing guru untuk lebih transparan dalam menceritakan penyebab permasalahan yang dihadapinya.

\section{Proses Pengambilan Keputusan Dilihat dari Dampaknya Bagi Guru ataupun Siswa}

Kepala sekolah sebelum melakukan proses pengambilan keputusan, terlebih dahulu mengenali jenis dan akibat dari pelanggaran tersebut. (Nurhayati, 2009) mengemukakan bahwa jenis pelanggaran yang seringkali terjadi adalah permasalahan kehadiran dan keterlambaran siswa, kelengkapan seragam, seperti seragam sekolah yang tidak lengkap (dasi, papan nama nametag dan ikat pinggang) serta peserta didik yang sering memakai sepatu yang tidak berwarna hitam. Dengan memperhatikan pelanggaran tersebut, kepala sekolah dapat menentukan keputusan dan kebijakan apa yang dapat segera ditentukan.

Pelanggaran yang dilakukan peserta didik antara lain masih adanya siswa yang tidak mengerjakan tugas, sering terlambat masuk kelas, dan hal ini tentunya akan mempengaruhi siswa dalam mengembangkan prestasi belajarnya lebih lanjut di sekolah. Maka pilihan awal yang dapat dilakukan oleh seorang kepala sekolah adalah dengan mengarahkan tenaga pendidik untuk mengawasi peserta didik di kelas.

Selanjutnya untuk pelanggaran siswa yang tidak mengenakan pakaian seragam yang sudah ditetapkan, hal ini juga mempunyai dampak negatif yang akan memperngaruhi perilaku siswa ketika mengikuti proses belajar mengajar di sekolah. Untuk menyikapi hal ini, tindakan yang dapat dilakukan kepala sekolah yaitu dengan mengambil keputusan untuk melakukan pengawasan kepada siswa dan meningkatkan tingkat kepedulian guru terhadap pelanggaran yang dilakukan oleh peserta didik. Ini sesuai 


\section{Kepemimpinan Kepala Sekolah dalam Pengambilan Keputusan di Sekolah Dasar - Dilla Yuliatika,}

Rusdinal, Nurhizrah Gistituati

DOI: https://doi.org/10.31004/edukatif.v3i5.972

dengan hasil penelitian (Hauserman, Cal P. dan Stick, 2013) yang menyatakan bahwa salah satu ciri kepala sekolah yang baik adalah yang mau mendengarkan dan mempunyai kepedulian terhadap siswanya.

Pelanggaran lain yang dilakukan oleh siswa adalah membuang sampah sembarangan, dan hal ini juga akan memberikan dampak terhadap perilaku siswa. Salah satu keputusan yang dapat diambil oleh kepala sekolah yaitu dengan menjalin komunikasi yang baik dn mengajak siswa untuk dapat menjaga kebersihan lingkungan sekolah. (Tokuan, 2015) dalam penelitiannya menjelaskan bahwa tindakan yang dilakukan oleh kepala sekolah yaitu dengan memberikan pengarahan kepada seluruh pihak yang ada di sekolah baik itu guru dan tenaga kependidikan untuk membiasakan seluruh siswa berpakaian rapi ke sekolah, dan dapat menjaga kebersihan lingkungan sekolah.

Pelanggaran tata tertib bagi siswa yang berkelahi dengan teman sekelas justru berdampak pada perilaku sosial yang pada umumnya akan merugikan perilaku anak-anak, kemudian, pada saat itu kepala sekolah dapat mengambil leputusan dengan mengawasi siswa secara langsung dan melakukan kerjasama yang dinamis dari guru dalam memberikan kemajuan kepada siswa.

Guru yang sering melanggar tata tertib sekolah dengan terlambat masuk kelas memiliki akibat yang merugikan, khususnya penurunan prestasi peserta didik, kompetensi dan pengetahuan peserta didik akan sulit berkembang, sehingga untuk situasi ini kepala sekolah dapat mengambil keputusan untuk melaksanakan pengawasan terhadap tenaga pendidikk dalam melakukan proses belajar mengajar siswa di kelas. Hal ini sesuai dengan penelitian (Irwansa, 2016) bahwa upaya sekolah merupakan hal penting untuk menyelesaikan berbagai permasalahan perilaku siswa terhadap pelaksanaan tata tertib sekolah. Selain itu, kepribadian gaya kepemimpinan kepala sekolah juga akan berdampak pada perannya dalam pengambilan keputusan di sekolah.

Untuk pelanggaran peraturan yang dilakukan guru, seperti melakukan sesuatu di depan siswa atau mengatakan hal-hal yang tidak pantas, cara yang dapat dilakukan kepala sekolah adalah menasihati guru untuk tidak menunjukkan, kebiasaan buruk di depan siswa. Kepala sekolah dapat menyelingi lelucon untuk membahas guru. Hasil penelitian (Omote, M.J., Thinguri, R.W., dan Moenga, 2015) juga menerangkan bahwa kepala sekolah harus mempunyai peranan paling terdepan, selalu ada untuk semua guru dan siswanya di sekolah, dapat menciptakan iklim sekolah yang baik, dapat menjalin kerjasama dan komunikasi yang baik dengan seluruh warga sekolah.

\section{KESIMPULAN}

Berdasarkan pemaparan tentang kepemimpinan kepala sekolah dalam pengambilan keputusan di SDN 01 Gurun di atas, dapat disimpulkan bahwa proses pengambilan keputusan terlihat dari identifikasi permasalahan terkait pelanggaran tata tertib sekolah oleh peserta didik dan pendidik, yaitu dengan mengenali atau mengidentifikasi macam-macam pelanggaran tata tertib tenaga pendidik dan peserta didik; mengetahui klasifikasi jenis pelanggaran taat tertib oleh tenaga pendidik dan peserta didik; menemukann dan menetapkan jenis-jenis sanksi dan solusi; dan melaksanakan keputusan atas jenis pelanggaran yang dilakukan oleh guru dan murid.

Proses pengambilan keputusan dilihat dari penyebab terjadinya pelanggaran tata tertib oleh tenaga pendidik dan peserta didik, lebih tepatnya kepala sekolah lebih mengenal siswa dan guru; memperhatikan jenis pelanggaran, mencari alasan yang menyebabkan terjadinya pelanggaran; mengurutkan penyebab pelanggaran yang dilakukan oleh siswa dan guru, dan temukan jawaban untuk masalah ini.

Proses pengambilan keputusan dilihat dari dampak pelanggarannya bagi tenaga pendidik dan peserta didik, yaitu kepala sekolah melihat jenis-jenis pelanggaran dan akibat atau dampak dari pelanggaran tersebut, baik terhadap siswa maupun guru; dilakukannya pengawasan bagi tenaga pendidik ketika melakukan proses belajar mengajar di kelas; pengawasan kepada peserta didik; menjalin komunikasi dan melakukan sosialisasi kepada peserta didik agar dapat lebih memperhatikan dan menjaga kebersihan. 
2950 Kepemimpinan Kepala Sekolah dalam Pengambilan Keputusan di Sekolah Dasar - Dilla Yuliatika, Rusdinal, Nurhizrah Gistituati

DOI: https://doi.org/10.31004/edukatif.v3i5.972

\section{UCAPAN TERIMA KASIH}

Penulis mengucapkan terimakasih terhadap semua pihak terkait dalam penelitian ini seperti kepala sekolah SDN 01 Gurun yang sudah mau memberikan izin untuk melakukan penelitian di sekolah ini sehingga penelitian ini dapat diselesaikan dengan maksimal.

\section{DAFTAR PUSTAKA}

Baharuddin Dan Umiarso. (2012). Kepemimpinan Pendidikan Islam. Yogyakarta : Ar-Ruzz Media.

Chaniago Aspizain. (2017). Pemimpin Dan Kepemimpinan (Pendekatan Teori \& Studi Kasus). Jakarta : Lentera Ilmu Cendekia.

Fitriwati, C., Sulistyarini, Dan P. (2015). Penerapan Sistem Poin Dalam Menanggulangi Siswa Yang Melanggar Aturan Di SMA N 2 Pontianak. Jurnal Pendidikan Dan Pembelajaran, Vol. 4, No. 6, 1-11.

Freire, Isabel Dan Amado, J. (2009). Managing And Handling Indisicipline In Schools: A Research Project. International Journal Of Violence And School, Vol. 8, 85-97.

Gutuza, Regis F. Dan Mapolisa, T. (2015). An Analysis Of The Causes Of Indiscipline Amongst Secondary School Pupils In Nyanga District. Global Journal Of Advanced Research, Vol. 2, No. 7, 1164-1171.

Hauserman, Cal P. Dan Stick, S. L. (2013). "The Leadership Teachers Want From Principals: Transformational." Canadian Journal Of Education/ Revue Canadienne De L'éducation, Vol. 36, No. 3, 184-203.

Irwansa, A. (2016). Analisis Pelaksanaan Tata Tertib Sekolah Pada Siswa Di SMK Negeri 1 Makassar. Jurnal Tomalebbi, Vol. 2, No. 1, 1-13.

Julia, E. (2013). Analisis Faktor Penyebab Dan Upaya Mengatasi Pelanggaran Tata Tertib Sekolah Pada SMA Wisuda Pontianak. Artikel Penelitian. Pontianak Universitas Tanjungpura.

Lee, Cheah; Abdullah, Abdul Gani Kanesan; Ismail, Aziah; Alizydeen, N. J. (2011). "How Democratic Leaders Empower Teachers Job Satisfaction? The Malaysian Case." International Journal Of Business And Social Science, Vol. 2, No.10, 251-257.

Marliana, Ayu, Dan T. (2013). Strategi Sekolah Dalam Menangani Pelanggaran Tata Tertib Sekola Pada Siswa Di SMPN 1 Papar Kediri. Kajian Moran Dan Kewarganegaraan, Volume 1, Nomor. 1, 232-246.

Miftah, T. (2012). Kepemimpinan Dalam Manajemen. Jakarta : Rajawali Press.

Ngwokabuenui, P. Y. (2015). Students' Indiscipline: Types, Causes And Possible Solutions: The Case Of Secondary Schools In Cameroon. Journal Of Education And Practice, Vol.6, No.22, 64-72.

Ningsih, B. Dan W. (2014). Peningkatan Disiplin. Siswa Dengan Lawayan. Informasi Media Film. Jurnal Empati, Volume 1, Nomor 1, 73-92.

Nurhayati, S. (2009). Pelaksanaan Tata Tertib Sistem Skoring, Dalam Peningkatan Disiplin Siswa Di SMPN 20 Malang. Skripsi. Malang : Universitas Negeri Malang.

Omote, M.J., Thinguri, R.W., Dan Moenga, M. . (2015). A Critical Analysis Of Acts Of Student Indiscipline And Management Strategies Employed By School Authorities In Public High Schools In Kenya. International Journal Of Education And Research, Vol. 3, No. 12, 1-10.

Pratama, F., Marsidin, S., \& Sabandi, A. (2020). Kebijakan Kepemimpinan Perubahan Kepala Sekolah Di Sekolah Dasar. Edukatif: Jurnal Ilmu Pendidikan, Volume 2 N(P-ISSN 2656-8063 E-ISSN 2656-8071), 227-231.

Purwanto Indra. (2019). Kepemimpinan. Kepala Sekolah Dalam Pengambiln Keputusan Di SMK Muhammadiyah Bumiayu Kabupaten Brebes. Institut Agama Islam Negeri Purwokerto.

Simuforosa, M. Dan Rosemary, N. (2014). Learner Indiscipline In Schools. Review Of Arts And Humanities, 
2951 Kepemimpinan Kepala Sekolah dalam Pengambilan Keputusan di Sekolah Dasar - Dilla Yuliatika, Rusdinal, Nurhizrah Gistituati

DOI: https://doi.org/10.31004/edukatif.v3i5.972

Vol. 3, No. 2, 79-88.

Suyitno. (2021). Analisis Kepemimpinan Kepala Sekolah, Penerapan Disiplin Dan Pengawasan Terhadap Etos Kerja. Edukatif: Jurnal Ilmu Pendidikan, Volume 3 (P-ISSN 2656-8063 E-ISSN 2656-8071), 728-737.

Tokuan, Y. M. (2015). Peran Guru Dalam Pembentukan Kepribadian Disiplin Siswa SMP Negeri 11 Kota Pontianak. Artikel. Pontianak: Universitas Tanjungpura. 